\title{
Effect of Blood Pressure on L-NAME-sensitive Component of Vasorelaxation in Adult Rats
}

\author{
A. PÚZSEROVÁ ${ }^{1}$, Z. CSIZMADIOVÁ ${ }^{1,2}$, I. BERNÁTOVÁ ${ }^{1}$ \\ ${ }^{1}$ Institute of Normal and Pathological Physiology, Centre of Excellence for Cardiovascular \\ Research, Slovak Academy of Sciences, Bratislava, ${ }^{2}$ Department of Animal Physiology and \\ Ethology, Faculty of Natural Sciences, Comenius University, Bratislava, Slovak Republic
}

Received July 4, 2007

Accepted August 28, 2007

On-line available September 5, 2007

\begin{abstract}
Summary
The aim of this study was to investigate nitric oxide (NO) production and L-NAME-sensitive component of endothelium-dependent vasorelaxation in adult normotensive Wistar-Kyoto rats (WKY), borderline hypertensive rats (BHR) and spontaneously hypertensive rats (SHR). Blood pressure (BP) of WKY, BHR and SHR (determined by tailcuff) was $111 \pm 3,140 \pm 4$ and $184 \pm 6 \mathrm{~mm} \mathrm{Hg}$, respectively. NO synthase activity (determined by conversion of $\left.{ }^{3} \mathrm{H}\right]-\mathrm{L}-$ arginine) was significantly higher in the aorta of BHR and SHR $v s$. WKY and in the left ventricle of SHR vs. both BHR and WKY. L-NAME-sensitive component of endothelium-dependent relaxation was investigated in the preconstricted femoral arteries using the wire myograph during isometric conditions as a difference between acetylcholine-induced relaxation before and after acute $\mathrm{N}^{\mathrm{G}}$-nitro-L-arginine methyl ester pre-treatment (L-NAME, $10^{-5} \mathrm{~mol} / \mathrm{l}$ ). Acetylcholineinduced vasorelaxation of SHR was significantly greater than that in WKY. L-NAME-sensitive component of vasorelaxation in WKY, BHR and SHR was $20 \pm 3 \%, 29 \pm 4 \%$ ( $<<0.05$ vs. WKY) and $37 \pm 3 \%$ ( $<<0.05$ vs. BHR), respectively. There was a significant positive correlation between BP and L-NAME-sensitive component of relaxation of the femoral artery. In conclusion, results suggest the absence of endothelial dysfunction in the femoral artery of adult borderline and spontaneously hypertensive rats and gradual elevation of L-NAME-sensitive component of vasorelaxation with increasing blood pressure.
\end{abstract}

\section{Key words}

Endothelial dysfunction $\bullet$ Prehypertensive period $\bullet$ Borderline hypertension $\bullet$ Spontaneously hypertensive rats $\bullet$ nitric oxide

\section{Introduction}

The tone of the vascular smooth muscle is a key determinant of local blood flow and peripheral resistance. The endothelium of blood vessels appears to play a central role in the regulation of tone and thus in blood pressure regulation via the synthesis and release of vasoactive substances (Das and Kumar 1995). Endothelial cells regulate the underlying smooth muscle layer by release of endothelium-derived relaxing factors such as nitric oxide (NO), prostacycline $\left(\mathrm{PGI}_{2}\right)$ and endothelium-derived hyperpolarizing factor (EDHF) as well as by liberation of vasoconstricting factors (Stankevičius et al. 2003). Injury of the endothelial 
monolayer can result in the impairment of vascular function and thus in impairment of blood pressure regulation.

$\mathrm{NO}$, one of the most potent vasodilators is synthesized from L-arginine by the enzyme nitric oxide synthase (NOS) (Moncada and Higgs 1993, Pecháňová and Šimko, 2007). There is evidence that NO is the main mediator of endothelium-dependent acetylcholineinduced relaxation in the large conduit arteries, whereas hyperpolarizing factor plays an important role in the resistance arteries (Hwa et al. 1994, Brandes et al. 2000).

The use of inhibitors of NOS showed the important role of NO in the regulation of blood pressure and in processes accompanying the development of cardiovascular disorders. It has been shown that chronic reduction of NO synthesis resulted in hypertension (Zatz and Baylis 1998, Gerová et al. 2004), reduced vasorelaxation (Török and Kristek 2001, Bernátová et al. 2002, Paulis et al. 2006) and myocardial hypertrophy (Šimko et al. 2004).

However, observations in the spontaneously hypertensive rats (SHR), which are widely used experimental model of human essential hypertension, showed considerable differences related to $\mathrm{NO}$ production and/or endothelial dysfunction (Vapaatalo et al. 2000). Thus, the role of NO and endothelial dysfunction in prehypertensive period and established hypertension is still conflicting. For such studies, besides of spontaneously hypertensive rats with blood pressure above $180 \mathrm{~mm} \mathrm{Hg}$, a model of borderline hypertensive rats (BHR) produced by the matting of spontaneously hypertensive dams with normotensive sires can be used (Lawler et al. 1980). Resting mean arterial pressure of adult offspring in the $F_{1}$ generation is in the range 130-150 mm Hg (Sanders and Lawler 1992, Mansi and Drolet 1997, Csizmadiová et al. 2006), which allows investigating vascular function in adult objects in prehypertensive period.

The purpose of this study was to determine the nitric oxide synthase activity in the aorta and left ventricle in rats with borderline and established hypertension. In addition, we investigated endotheliumdependent vasorelaxation and L-NAME-sensitive component of this relaxation in the femoral artery of BHR and SHR in comparison with age-matched normotensive Wistar-Kyoto rats. Furthermore, we investigated relation between L-NAME-sensitive component of vasorelaxation and blood pressure.

\section{Methods}

Animals

All rats used in the study, $\mathrm{n}=10$ in each group, were born in our animal facility in order to keep the same environmental background of all animals. Three groups of 20-week-old male rats were used in the study: normotensive Wistar-Kyoto rats (WKY), spontaneously hypertensive rats (SHR) and borderline hypertensive rats. BHR were $F_{1}$ offspring of SHR dams and normotensive WKY sires. Rats were housed at $22-24{ }^{\circ} \mathrm{C}$ on a $12: 12 \mathrm{~h}$ dark-light cycle and maintained on a standard pellet diet and tap water ad libitum. All procedures used were in accordance with institutional guidelines and they were approved by the State Veterinary and Food Administration of the Slovak Republic.

One week before experimentation, the rats were handled and accustomed to the tail-cuff procedure of blood pressure recording. Blood pressure (BP) and heart rate (HR) were determined between 9.00-12.00 $\mathrm{h}$ and were calculated as average values of 5-6 measurements. Rats were killed by decapitation after a brief $\mathrm{CO}_{2}$ anesthesia. Body mass (BM) as well as the wet mass of the left ventricle (LV) and right ventricle (RV) were determined for calculation of their relative masses (LV/BM, RV/BM).

\section{NO synthase activity}

NO synthase activity was measured in the homogenates of the aorta and left ventricle by determination of $\left[{ }^{3} \mathrm{H}\right]$-L-citrulline (L-Cit) formation from $\left[{ }^{3} \mathrm{H}\right]$-L-arginine (MP Biomedicals, USA), as described previously (Bredt and Snyder 1990), with minor modifications. Briefly, crude homogenates of the aorta and $\mathrm{LV}$ containing $200 \mathrm{mg}$ of wet tissue per $1 \mathrm{ml}$ of homogenization solution containing $50 \mathrm{mmol} / \mathrm{l}$ Tris- $\mathrm{HCl}$, pH 7.4 and $1 \%$ Protease Inhibitor Cocktail (Sigma, Germany) were centrifuged at $10000 \mathrm{~g}$ for $15 \mathrm{~min}$ at $4{ }^{\circ} \mathrm{C}$. After centrifugation, $50 \mu \mathrm{l}$ of supernatant was incubated in the presence of $10 \mu \mathrm{mol} / 1\left[{ }^{3} \mathrm{H}\right]$-L-arginine (specific activity $5 \mathrm{GBq} / \mathrm{mmol}$, about $100000 \mathrm{dpm}), 5 \mu \mathrm{g} / \mathrm{ml}$ calmodulin, $0.5 \mathrm{mmol} / 1 \beta$-NADPH, $250 \mu \mathrm{mol} / 1$ tetrahydrobiopterin, 4 $\mu \mathrm{mol} / 1 \mathrm{FAD}, 4 \mu \mathrm{mol} / 1 \mathrm{FMN}, 1 \mathrm{mmol} / 1 \mathrm{Ca}^{2+}, 1 \mathrm{mmol} / 1$ $\mathrm{Mg}^{2+}$ in the total volume of $100 \mu \mathrm{l}$. After 20-min incubation at $37{ }^{\circ} \mathrm{C}$, the reaction was stopped by $1 \mathrm{ml}$ of ice-cold stop solution containing $20 \mathrm{mmol} / \mathrm{l} \mathrm{HEPES}, \mathrm{pH}$ 5.5, $2 \mathrm{mmol} / \mathrm{l}$ EDTA, $2 \mathrm{mmol} / \mathrm{l}$ EGTA and $1 \mathrm{mmol} / 1 \mathrm{~L}-\mathrm{Cit}$ and applied to 50WX-8 Dowex columns ( $\mathrm{Na}^{+}$form). $\left[{ }^{3} \mathrm{H}\right]-$ L-citrulline was eluted by $1 \mathrm{ml}$ of water and determined by 
liquid scintillation counting. NO synthase activity was expressed as $\mathrm{pmol} / \mathrm{min} / \mathrm{mg}$ of proteins.

\section{Vascular responses}

Femoral arteries were carefully dissected out, immediately immersed in Krebs-Ringer solution and cleaned of adipose or connective tissue. Then arteries were cut into segments (approximately $1 \mathrm{~mm}$ long) and mounted as ring-shaped preparations in the Mulvany-Halpern's style small vessel wire myograph (Mulvany and Halpern 1977) chamber (Dual Wire Myograph System 410A, DMT A/S, Aarhus, Denmark) to determine the vascular reactivity during isometric conditions. Relaxation was determined in the arteries (with mean normalized internal diameter $611 \pm 20 \mu \mathrm{m})$ with intact endothelium, as described elsewhere (Púzserová et al. 2006). To assess relaxation, dose-response curves were constructed using endotheliumdependent vasodilator acetylcholine (ACh) after the precontraction of the segments with phenylephrine $\left(10^{-4}\right.$ $\mathrm{mol} / \mathrm{l})$. ACh was applied in cumulative manner $\left(10^{-9}-10^{-5}\right.$ $\mathrm{mol} / \mathrm{l}$ ) when the contractile response to phenylephrine reached a plateau. When the dose-dependent relaxing curve was completed, the drugs were washed-out (with $4 \times 10 \mathrm{ml}$ of Krebs-Ringer solution) and the same experiment was repeated after 20-min preincubation with the nitric oxide synthase inhibitor $\mathrm{N}^{\mathrm{G}}$-nitro-L-arginine methyl ester (L-NAME) in the bath medium. The difference between $\mathrm{ACh}$-induced response before and after preincubation with L-NAME $\left(10^{-5} \mathrm{~mol} / \mathrm{l}\right)$ represented LNAME-sensitive component of ACh-induced vasodilatation at the given concentration of L-NAME. The extent of relaxation was expressed as the percentage of precontraction and the average value of vasorelaxation was calculated as a mean value of vasorelaxation reached in the groups based on the individual dose-response curves.

All the chemicals used were purchased from Sigma-Aldrich (Germany). All drugs were dissolved in distilled water and concentrations are expressed as final concentration in the myograph chamber.

\section{Statistical analysis}

Data were analyzed using Statistica 6.0 (Statsoft, Inc., Tulsa, OK). All results are presented as mean \pm S.E.M. Vascular function was analyzed using two-way ANOVA. All other data were analyzed using one-way ANOVA. Analyses were followed by Duncan's post-hoc test. Values were considered to differ significantly when $\mathrm{p}<0.05$.
Table 1. Basic biometric and cardiovascular parameters of Wistar-Kyoto rats (WKY), borderline hypertensive rats (BHR) and spontaneously hypertensive rats (SHR).

\begin{tabular}{lllll}
\hline & n & WKY & BHR & SHR \\
\hline$B M(g)$ & 10 & $390 \pm 11$ & $400 \pm 10$ & $339 \pm 5^{*+}$ \\
$B P(m m ~ H g)$ & 10 & $111 \pm 3$ & $140 \pm 4 *$ & $184 \pm 6^{*+}$ \\
$H R(b p m)$ & 10 & $403 \pm 11$ & $411 \pm 9$ & $448 \pm 10^{*}$ \\
$L V / B M(m g / 100 g)$ & 8 & $148 \pm 3$ & $161 \pm 3 *$ & $226 \pm 5^{*+}$ \\
$R V / B M(m g / 100 g)$ & 8 & $58 \pm 1$ & $58 \pm 2$ & $69 \pm 5^{*+}$ \\
\hline
\end{tabular}

BM - body mass; BP - blood pressure; HR - heart rate; LV - left ventricle; RV - right ventricle. Results are mean \pm S.E.M. $* \mathrm{p}<0.05$ vs. WKY, ${ }^{+} \mathrm{p}<0.05$ vs. BHR.

\section{Results}

\section{Basic parameters}

Basic biometric and cardiovascular parameters ( $\mathrm{n}=8-10)$ of WKY, BHR and SHR rats are shown in Table 1. Body mass was significantly reduced in SHR when compared to both WKY and BHR. Blood pressure was significantly higher in both BHR and SHR compared to age-matched WKY rats. BP of BHR was elevated by about $26 \%$ compared to WKY. In SHR, BP was elevated vs. WKY and BHR by about $66 \%$ and $31 \%$, respectively. There were significant differences in the $\mathrm{LV} / \mathrm{BM}$ ratio among $\mathrm{WKY}, \mathrm{BHR}$ and SHR rats. The augmentation of $\mathrm{BP}$ was accompanied by increased $\mathrm{LV} / \mathrm{BM}$ ratio in both BHR and SHR. Moreover, relative mass of left ventricle was elevated in SHR group compared to BHR group. HR and the RV/BM ratio were similar in WKY and BHR, but both parameters were elevated in SHR compared to WKY.

\section{Nitric oxide synthase activity}

Nitric oxide synthase activity $(n=6$ in each group) in the aorta of WKY rats was $2.63 \pm 0.18$ $\mathrm{pmol} / \mathrm{min} / \mathrm{mg}$ and in the left ventricle was $2.19 \pm 0.42$ $\mathrm{pmol} / \mathrm{min} / \mathrm{mg}$. NOS activity in the aorta of BHR and SHR rats was significantly higher than that in WKY rats (Fig. 1). In the left ventricle, nitric oxide synthase activity was elevated in SHR vs. both WKY and BHR.

\section{Endothelium-dependent relaxation}

The average acetylcholine-induced relaxation of the femoral artery in WKY, BHR and SHR $(n=6$ in each group) was $61 \pm 5 \%, 63 \pm 6 \%$ (ns), $79 \pm 4 \%$ ( $<<0.05$ vs. WKY), respectively. In SHR, relaxant response to 

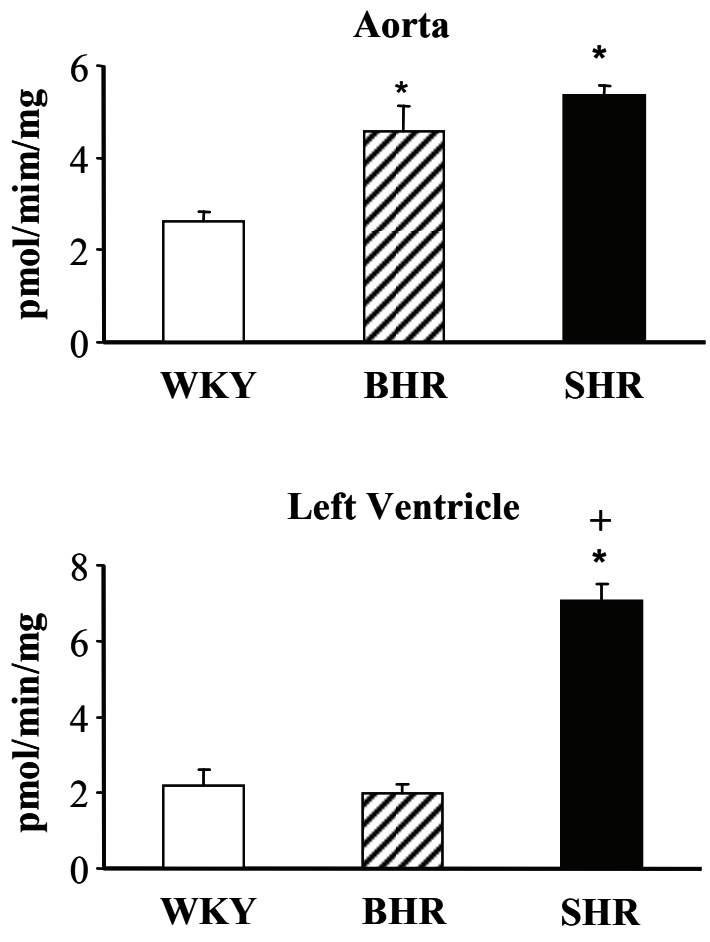

Fig. 1. Nitric oxide synthase activity in Wistar-Kyoto (WKY), borderline hypertensive (BHR) and spontaneously hypertensive (SHR) rats. Results are mean \pm S.E.M. $* p<0.05$ vs. WKY; ${ }^{+} \mathrm{p}<0.05$ vs. BHR.

acetylcholine was markedly increased in the range of concentration $5.10^{-9}-10^{-7} \mathrm{~mol} / 1$ compared to normotensive group $(\mathrm{p}<0.05)$ and the dose-response curve to acetylcholine was shifted to the left indicating increased sensitivity to acetylcholine. There was no significant difference in relaxant response to acetylcholine between WKY and BHR. Acute blockade of nitric oxide synthesis by L-NAME $\left(10^{-5} \mathrm{~mol} / \mathrm{l}\right)$ significantly reduced vasorelaxations in all groups investigated. Individual dose-response curves in the absence and presence of the NOS inhibitor L-NAME are presented in Figure 2. L-NAME-sensitive component of ACh-induced vasorelaxation was significantly increased in BHR ( $<<0.05$ vs. WKY) and SHR ( $<<0.05$ vs. BHR) (Fig. 3A). There was a significant positive correlation between L-NAME-sensitive component of vasorelaxation and $\mathrm{BP}(\mathrm{r}=0.614, \mathrm{p}<0.007, \mathrm{n}=18$, Fig. 3B).

\section{Discussion}

This study investigated vascular NO production and endothelium-dependent relaxation of the femoral artery in adult rats with one or two hypertensive progenitors. The most important finding of this study was that magnitude of L-NAME-sensitive component of
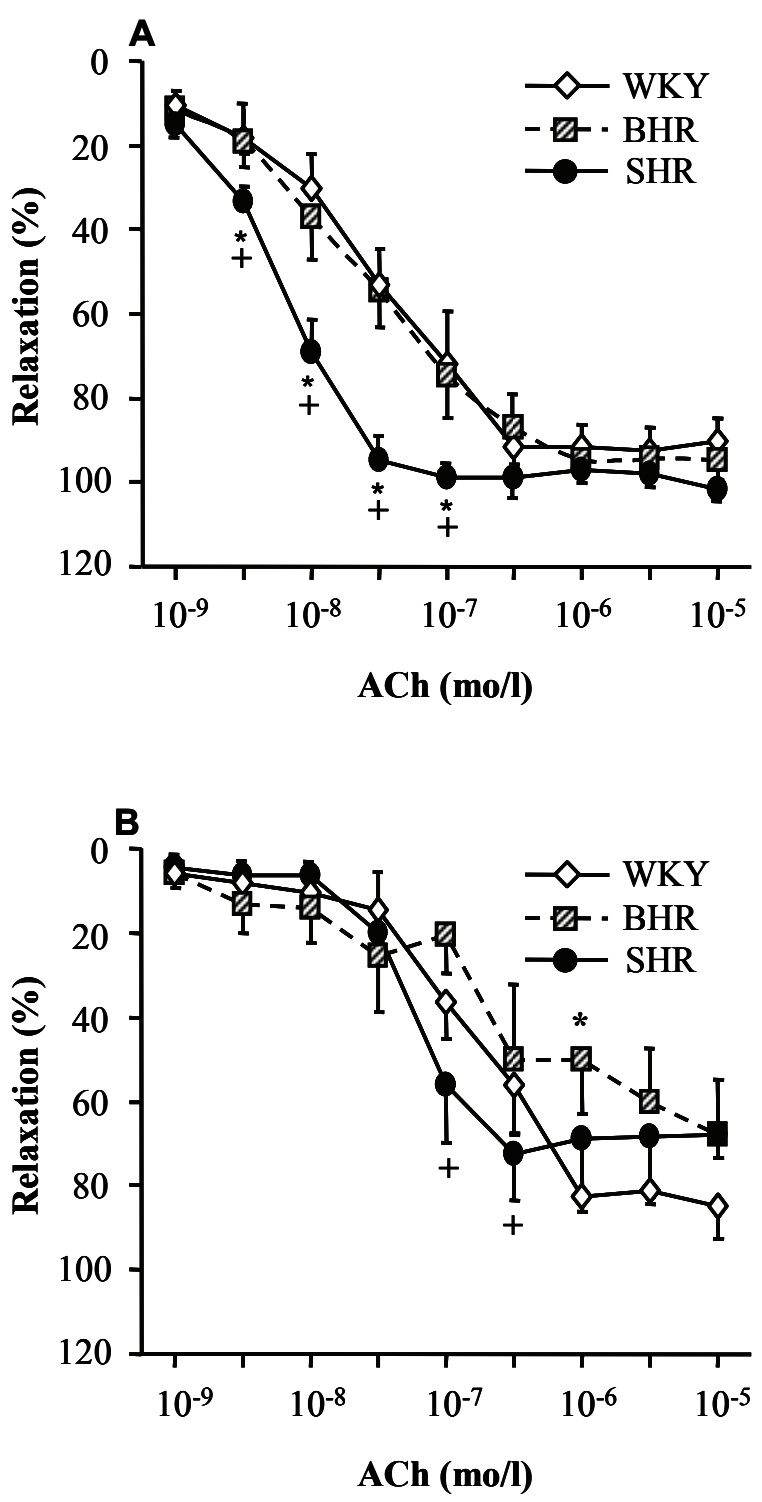

Fig. 2. Concentration-response curves of acetylcholine (ACh)induced relaxation of the femoral arteries of Wistar-Kyoto (WKY), borderline hypertensive (BHR) and spontaneously hypertensive (SHR) rats in the absence $(\mathbf{A})$ and in the presence (B) of $N^{G}$ nitro-L-arginine methyl ester (L-NAME, $\left.10^{-5} \mathrm{~mol} / \mathrm{I}\right)$. Results are mean \pm S.E.M. ${ }^{*} \mathrm{p}<0.05 \mathrm{Vs}$. WKY at the same concentration of $\mathrm{ACh} ;{ }^{+} \mathrm{p}<0.05$ vs. BHR at the same concentration of ACh.

ACh-induced relaxation in the femoral artery of adult BHR and SHR positively correlated with BP. Furthermore, vascular NO production in BHR and SHR was greater than that in normotensive rats and AChinduced relaxation of the femoral artery of SHR rats was greater that in WKY.

In this study elevated blood pressure was accompanied by an increase of relative left ventricle mass in both SHR and BHR indicating left ventricular hypertrophy. Blood pressure level was closely associated with the severity of cardiac hypertrophy. Since left 

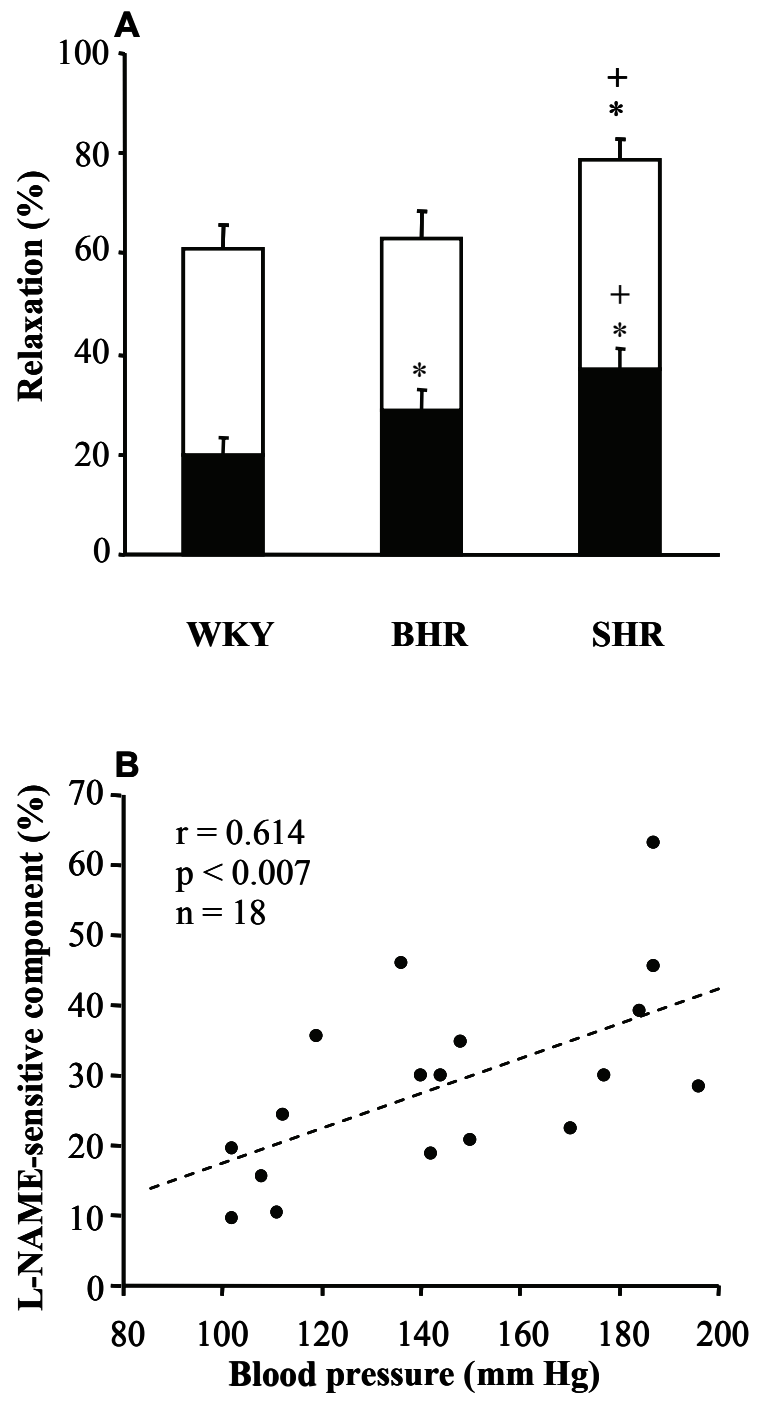

Fig. 3. Average values of acetylcholine-induced relaxation (entire column) of the femoral artery and L-NAME-sensitive component of relaxation (black column) of Wistar-Kyoto (WKY), borderline hypertensive (BHR) and spontaneously hypertensive (SHR) rats (A) and correlation between L-NAME-sensitive component of relaxation and blood pressure (B). Results are mean \pm S.E.M. ${ }^{*} \mathrm{p}<0.05$ vs. WKY; ${ }^{+} \mathrm{p}<0.05$ vs. BHR.

ventricular hypertrophy is the result of interaction of hemodynamic overload and local non-hemodynamic factors, NO may play a significant role in its development. Indeed, pharmacological inhibition of NO production can induce hypertrophic myocardial growth (Kristek and Gerová 1996, Šimko and Šimko 2000) as well as damage myocardial structure and function (Okruhlicová et al. 2000, Tribulová et al. 2000). However, our data showed the occurrence of left ventricular hypertrophy without alterations in NO production in BHR and even in the presence of increased NOS activity in SHR. This suggests that hemodynamic factors and/or other local growth factors rather than NO modify myocardial growth. However, it is worthy to note that local NO bioavailability in the heart may be either significantly reduced by oxidative stress (Pecháňová et al. 2007) or it may be still insufficient to compensate increased sympathetic activity of hypertensive rats which may induced hypertrophy (Kuneš et al. 2004, Pecháňová et al. 2004).

The question whether endothelial dysfunction is a consequence or a cause of hypertension remains still open. This is documented by several studies showing impaired, unaltered or improved endothelial function in spontaneously hypertensive rats. There are many studies, which showed that reduced NO production led to attenuation of vasodilatation, elevation of vasoconstriction and to the development of hypertension in normotensive rats (Holécyová et al. 1996, Török and Kristek 2001, Šimko et al. 2004, Fialová et al. 2008). Based on this knowledge, it may be assumed that the development of hypertension in spontaneously hypertensive rats may be associated with NO deficiency and/or endothelial dysfunction. Indeed, several authors observed reduced relaxation of various conduit and resistance arteries such as the aorta, iliac artery, basilar artery and coronary and mesenteric arteries of adult SHR rats (Mayhan 1990, Wuorela et al. 1994, Küng and Lüscher 1995, Pourageaud and Freslon 1995, Čačányiová et al. 2006). Reduced relaxation of the aorta was also observed by Konishi and Su (1983). However, the same study showed the improvement of vasodilatation in the femoral artery of SHR as it was found in our study. Similarly, greater magnitude of the ACh-induced vasodilatation was observed in the mesenteric arteries of adult SHR (Chang et al. 2002). Moreover, Gerová et al. (2005) showed enhanced hypotensive response to ACh in adult SHR in vivo, which was associated with improved relaxation of resistance arteries but attenuated relaxation of the conduit iliac artery in vitro. In adult BHR, relaxation of the thoracic aorta was greater than in normotensive controls, while no differences were observed in the mesenteric artery (Stratton et al. 1994, Fuchs et al. 1998). In addition to the above mentioned studies, no differences were observed in the magnitude of ACh-induced relaxation of the carotid artery and aorta of SHR compared with normotensive rats (Török and Kristek 2001). Altogether, these findings suggest that endothelial dysfunction in hypertension may not be present in all parts of vascular tree and it appears to be the consequence rather than a cause of hypertension in rats. 
In this study, simultaneously with elevated vasorelaxation in SHR rats, we observed that reduction of ACh-induced relaxation after acute NO synthase inhibition (at the dose of L-NAME $10^{-5} \mathrm{~mol} / \mathrm{l}$ ) was more pronounced in SHR and BHR that in WKY. This increased sensitivity to L-NAME suggests that vascular function of rats with positive family history of hypertension was more NO-dependent than in normotensive rats. Elevated sensitivity of relaxation of the femoral artery of SHR to acute NO deficiency was also observed in our previous study when we used lower dose of L-NAME $\left(10^{-6} \mathrm{~mol} / \mathrm{l}\right)$. Although this dose had no effect on ACh-induced relaxation in BHR rats, it significantly attenuated relaxation in SHR (Bernátová et al. 2006). Thus, the sensitivity of endothelium-dependent vasorelaxation to acute NO deficiency was the greatest in rats with established hypertension and the lowest in normotensive rats.

Regarding NO production, reduced expression of endothelial NO synthase in coronary arterioles and aorta of SHR was demonstrated (Crabos et al. 1997, Chou et al. 1998). On the other hand, several studies showed that NO formation and/or release were upregulated in cardiovascular system of SHR (Hayakawa and Raij 1997, Nava et al. 1998, Vaziri et al. 1998). Physiological stimuli for NO production in blood vessels are shear stress (Rubányi et al. 1986), cyclic strain and intraluminal blood pressure, which may increase NO production in vitro as well as in vivo (Buga et al. 1991,
Awolesi et al. 1994, Hoyer et al. 1996). Elevated constitutive NOS activity in SHR was observed in the aorta and left ventricle and there was a striking positive correlation between NO production and blood pressure (Hayakawa and Raij 1997). Because NO is known to counterbalance the effect of sympathetic stimulation on the peripheral as well as central level (Safar et al. 2001, Stefano et al. 2006), elevated basal vascular NO synthesis in rats with a positive family history of hypertension may be considered as an adaption mechanism, preventing them from excessive BP elevation.

In conclusion, our results showed that adult rats with borderline and established hypertension did not develop endothelial dysfunction and they were able to maintain high levels of vascular NO production. Moreover, we showed a positive correlation between BP and magnitude of L-NAME-sensitive component of vasorelaxation of adult rats with elevated blood pressure. This suggests that reduction of cardiovascular NO production and endothelial dysfunction do not participate in the initiation of genetic hypertension in these experimental models.

\section{Acknowledgements}

This study was supported by the grants Nos. APVT-51018004, APVT-51-059505 and VEGA 2/7064/26. The authors would like to thank Mrs. Yvonne Hanáčková and Mrs. Jana Pet'ová for their excellent technical assistance.

\section{References}

AWOLESI MA, WIDMANN MD, SESSA WC, SUMPIO BE: Cyclic strain increases endothelial nitric oxide synthase activity. Surgery 116: 439-444, 1994.

BERNÁTOVÁ I, PECHÁŇOVÁ O, BABÁL P, KYSELÁ S, ŠTVRTINA S, ANDRIANTSITOHAINA R: Wine polyphenols improve cardiovascular remodeling and vascular function in NO-deficient hypertension. $\mathrm{Am} J$ Physiol 282: H942-H948, 2002.

BERNÁTOVÁ I, CSIZMADIOVÁ Z, KOPINCOVÁ J, PÚZSEROVÁ A: Effect of chronic stress on vascular responses in rats with borderline and spontaneous hypertension. Physiol Res 55: 15P, 2006.

BRANDES RP, SCHMITZ-WINNENTHAL FH, FELETOU M, GODECKE A, HUANG PL, VANHOUTTE PM, FLEMING I, BUSSE R: An endothelium-derived hyperpolarizing factor distinct from NO and prostacyclin is a major endothelium-dependent vasodilator in resistance vessels of wild-type and endothelial NO synthase knockout mice. Proc Natl Acad Sci USA 97: 9747-9752, 2000.

BREDT DS, SNYDER SH: Isolation of nitric oxide synthetase, a calmodulin-requiring enzyme. Proc Natl Acad Sci USA 87: 682-685, 1990.

BUGA GM, GOLD ME, FUKUTO JM, IGNARRO LJ: Shear stress-induced release of nitric oxide from endothelial cells grown on beds. Hypertension 17: 187-193, 1991.

ČAČÁNYIOVÁ S, CEBOVÁ M, KUNEŠ J, KRISTEK F: Comparison of vascular function and structure of iliac artery in spontaneously hypertensive and hereditary hypertriglyceridemic rats. Physiol Res 55 (Suppl 1): S73-S80, 2006. 
CHANG HR, LEE RP, WU CY, CHEN HI: Nitric oxide in mesenteric vascular reactivity: a comparison between rats with normotension and hypertension. Clin Exp Pharmacol Physiol 29: 275-280, 2002.

CHOU TC, YEN MH, LI CY, DING YA: Alterations of nitric oxide synthase expression with aging and hypertension in rats. Hypertension 31: 643-648, 1998.

CRABOS M, COSTE P, PACCALIN M, TARIOSSE L, DARET D, BESSE P, BONORON-ADELE S: Reduced basal NO-mediated dilation and decreased endothelial NO-synthase expression in coronary vessels of spontaneously hypertensive rats. J Mol Cell Cardiol 29: 55-65, 1997.

CSIZMADIOVÁ Z, KOPINCOVÁ J, JENDEKOVÁ L, BERNÁTOVÁ I: Nitric oxide synthase activity and blood pressure in the rats with various family history of hypertension. Physiol Res 55: 7P, 2006.

DAS S, KUMAR KN: Nitric oxide: its identity and role in blood pressure control. Life Sci 57: 1547-1556, 1995.

FIALOVÁ M, DLUGOŠOVÁ K, OKRUHLICOVÁ L, KRISTEK F, MANOACH M, TRIBULOVÁ N: Adaptation of the heart to hypertension is associated with maladaptive gap junction connexin-43 remodelling. accepted by Physiol Res in press, 2008.

FUCHS LC, HOQUE AM, CLARKE NL: Vascular and hemodynamic effects of behavioral stress in borderline hypertensive and Wistar-Kyoto rats. Am J Physiol 274: R375-R382, 1998.

GEROVÁ M, TÖRÖK J, PECHÁŇOVÁ O, MATÚŠKOVÁ J: Rilmenidine prevents blood pressure increase in rats with compromised nitric oxide production. Acta Pharmacol Sin 25: 1640-1646, 2004.

GEROVÁ M, KRISTEK F, ČAČÁNYIOVÁ S, CEBOVÁ M: Acetylcholine and bradykinin enhance hypotension and affect the function of remodeled conduit arteries in SHR and SHR treated with nitric oxide donors. Braz J Med Biol Res 38: 959-966, 2005.

HAYAKAWA H, RAIJ L: The link among nitric oxide synthase activity, endothelial function, and aortic and ventricular hypertrophy in hypertension. Hypertension 29: 235-241, 1997.

HOLÉCYOVÁ A, TÖRÖK J, BERNÁTOVÁ I, PECHÁŇOVÁ O: Restriction of nitric oxide rather than elevated blood pressure is responsible for alterations of vascular responses in nitric oxide-deficient hypertension. Physiol Res 45: 317-321, 1996.

HOYER J, KOHLER R, HAASE W, DISTLER A: Up-regulation of pressure-activated $\mathrm{Ca}^{2+}$-permeable cation channel in intact vascular endothelium of hypertensive rats. Proc Natl Acad Sci USA 93: 11253-11258, 1996.

HWA JJ, GHIBAUDI L, WILLIAMS P, CHATTERJEE M: Comparison of acetylcholine-dependent relaxation in large and small arteries of rat mesenteric vascular bed. Am J Physiol 266: H952-H958, 1994.

KONISHI M, SU C: Role of endothelium in dilator responses of spontaneously hypertensive rat arteries. Hypertension 5: 881-886, 1983.

KRISTEK F, GEROVÁ M: Long-term NO synthase inhibition affects heart weight and geometry of coronary and carotid arteries. Physiol Res 45: 361-367, 1996.

KUNEŠ J, HOJNÁ S, KADLECOVÁ M, DOBEŠOVÁ Z, RAUCHOVÁ H, VOKURKOVÁ M, LOUKOTOVÁ J, PECHÁŇOVÁ O, ZICHA J: Altered balance of vasoactive systems in experimental hypertension: the role of relative NO deficiency. Physiol Res 53 (Suppl 1): S23-34, 2004.

KÜNG CF, LÜSCHER TF: Different mechanisms of endothelial dysfunction with aging and hypertension in rat aorta. Hypertension 25: 194-200, 1995.

LAWLER JE, BARKER GF, HUBBARD JW, SCHAUB RG: Pathophysiological changes associated with stressinduced hypertension in the borderline hypertensive rat. Clin Sci 59 (Suppl 6): S307-S310, 1980.

MANSI JA, DROLET G: Chronic stress induces sensitization in sympathoadrenal responses to stress in borderline hypertensive rats. Am J Physiol 272: R813-R820, 1997.

MAYHAN WG: Impairment of endothelium-dependent dilatation of basilar artery during chronic hypertension. $A m J$ Physiol 259: H1455-H1462, 1990.

MONCADA S, HIGGS A: The L-arginine-nitric oxide pathway. N Engl J Med 329: 2002-2012, 1993.

MULVANY MJ, HALPERN W: Contractile properties of small arterial resistance vessels in spontaneously hypertensive and normotensive rats. Circ Res 41: 19-26, 1977.

NAVA E, FARRÉ AL, MORENO C, CASADO S, MOREAU P, COSENTINO F, LÜSCHER TF: Alterations to the nitric oxide pathway in the spontaneously hypertensive rat. J Hypertens 16: 609-615, 1998. 
OKRUHLICOVÁ L, TRIBULOVÁ N, BERNÁTOVÁ I, PECHÁŇOVÁ O: Induction of angiogenesis in NO-deficient rat heart. Physiol Res 49: 71-76, 2000.

PAULIS L, ZICHA J, KUNEŠ J, HOJNÁ S, KOJŠOVÁ S, PECHÁŇOVÁ O, ŠIMKO F: Regression of L-NAMEinduced hypertension: The role of NO-pathway and endothelium-derived constricting factor. $J$ Hypertens 24 (Suppl 4): S7, 2006.

PECHÁŇOVÁ O, DOBEŠOVÁ Z, ČEJKA J, KUNEŠ J, ZICHA J: Vasoactive systems in L-NAME hypertension: the role of inducible nitric oxide synthase. J Hypertens 22: 167-173, 2004.

PECHÁŇOVÁ O, ŠIMKO F: The role of nitric oxide in the maintenance of vasoactive balance. Physiol Res $\mathbf{5 6}$ (Suppl 2): S7-S16, 2007.

PECHÁŇOVÁ O, ZICHA J, PAULIS L, ZENEBE W, DOBEŠOVÁ Z, KOJŠOVÁ S, JENDEKOVÁ L, SLÁDKOVÁ M, DOVINOVÁ I, ŠIMKO F, KUNEŠ J: The effect of N-acetylcysteine and melatonin in adult spontaneously hypertensive rats with established hypertension. Eur J Pharmacol 561: 129-136, 2007.

POURAGEAUD F, FRESLON JL: Endothelial and smooth muscle properties of coronary and mesenteric resistance arteries in spontaneously hypertensive rats compared to WKY rats. Fundam Clin Pharmacol 9: 37-45, 1995.

PÚZSEROVÁ A, CSIZMADIOVÁ Z, ANDRIANTSITOHAINA R, BERNÁTOVÁ I: Vascular effects of red wine polyphenols in chronic stress-exposed Wistar-Kyoto rats. Physiol Res 55 (Suppl 1): S39-S47, 2006.

RUBÁNYI GM, ROMERO JC, VANHOUTTE PM: Flow-induced release of endothelium-derived relaxing factor. $A m$ J Physiol 250: H1145-H1149, 1986.

SAFAR M, CHAMIOT-CLERC P, DAGHER G, RENAUD JF: Pulse pressure, endothelium function, and arterial stiffness in spontaneously hypertensive rats. Hypertension 38: 1416-1421, 2001.

SANDERS BJ, LAWLER JE: The borderline hypertensive rat (BHR) as a model for environmentally-induced hypertension: a review and update. Neurosci Biobehav Rev 16: 207-217, 1992.

ŠIMKO F, ŠIMKO J: The potential role of nitric oxide in the hypertrophic growth of the left ventricle. Physiol Res 49: 37-46, 2000.

ŠIMKO F, MATÚŠKOVÁ J, LUPTÁK I, KRAJČÍROVIČOVÁ K, KUCHARSKÁ J, GVOZDJÁKOVÁ A, BABÁL P, PECHÁŇOVÁ O: Effect of simvastatin on remodeling of the left ventricle and aorta in L-NAME-induced hypertension. Life Sci 74: 1211-1224, 2004.

STANKEVIČIUS E, KEVELAITIS E, VAINORIUS E, SIMONSEN U: Role of nitric oxide and other endotheliumderived factors. Medicina (Kaunas) 39: 333-341, 2003.

STEFANO GB, FRICCHIONE GL, ESCH T: Relaxation: molecular and physiological significance. Med Sci Monit 12: HY21-HY31, 2006.

STRATTON DB, MORROW RJ, SANDERS BJ: Vascular responsiveness in the unstressed borderline hypertensive rat. Clin Exp Hypertens 16: 105-117, 1994.

TÖRÖK J, KRISTEK F: Functional and morphological pattern of vascular responses in two models of experimental hypertension. Exp Clin Cardiol 6: 142-148, 2001.

TRIBULOVÁ N, OKRUHLICOVÁ L, BERNÁTOVÁ I, PECHÁŇOVÁ O: Chronic disturbances in NO production results in histochemical and subcellular alterations of the rat heart. Physiol Res 49: 77-88, 2000.

VAPAATALO H, MERVAALA E, NURMINEN ML: Role of endothelium and nitric oxide in experimental hypertension. Physiol Res 49: 1-10, 2000.

VAZIRI ND, NI Z, OVEISI F: Upregulation of renal and vascular nitric oxide synthase in young spontaneously hypertensive rats. Hypertension 31: 1248-1254, 1998.

WUORELA H, ARVOLA P, KAHONEN M, VAPAATALO H, PORSTI I: Arterial smooth muscle responses in adult and moderately aged spontaneously hypertensive rats. Pharmacol Toxicol 74: 167-173, 1994.

ZATZ R, BAYLIS C: Chronic nitric oxide inhibition model six years on. Hypertension 32: 958-964, 1998.

\section{Corresponding author}

I. Bernátová, Institute of Normal and Pathological Physiology, Slovak Academy of Sciences, Sienkiewiczova 1, Bratislava 813 71, Slovak Republic. E-mail: Iveta.Bernatova@savba.sk 